Modern Asian Studies 55, 4 (202I) p. I4I I. C Cambridge University Press 2020. This is an Open Access article, distributed under the terms of the Creative Commons Attribution licence (http://creativecommons.org/licenses/by/4.o/), which permits unrestricted re-use, distribution, and reproduction in any medium, provided the original work is properly cited.

doi:Io.Iol7/Soo26749X200004I4 First published online 22 September 2020

\title{
ERRATUM
}

\section{The Modernity of Caste and the Market Economy DAVID MOSSE}

SOAS University of London

Email:dm21@soas.ac.uk

doi: Io.Io17/Soo26749XIgoooo39. Published by Cambridge University Press, 30 October 2019.

The published version of this article ${ }^{\mathrm{I}}$ is missing part of the sentence referring to Rupa Viswanath's work on page 1234. The full sentence should read:

"Her recent book, The Pariah Problem (2014b), describes a chain of events and reactions that led a Dalit condition of agrarian enslavement to be 'spiritualized' (rendering untouchability religious) and missionaries to be opposed as a threat to Hindu religion rather than as a challenge to landlord abuse of Dalit labour."

The Publisher apologises for this error.

'D. Mosse, 'The Modernity of Caste and the Market Economy', Modern Asian Studies, vol. 54, no. 4, 2020, pp. I225-7I. doi:Io.IoI7/ Soo26749Xigoooo39. 